\title{
La delegación del PCE en México (1939-1956) Origen y límite de una voluntad de liderazgo de la oposición ${ }^{1}$
}

\author{
Pablo Jesús CarRión Sánchez
}

\begin{abstract}
RESUMEN
A través del estudio de la Delegación del PCE en México se analizan algunas claves esenciales del exilio político de 1939. En paralelo a la primera fase de la Dictadura los desterrados tratan de estructurar plataformas de oposición para derribarla. En ellas se observa la voluntad de liderazgo del PCE en contraste con su relativo aislamiento tanto del resto del exilio como de la propia política mexicana.
\end{abstract}

PALABRAS CLAVE

Exilio republicano. Franquismo. México. PCE.

\begin{abstract}
Through the study of the Delegation of the PCE in Mexico some essential keys of the political exile of 1939 are analysed. In parallel to the first phase of the Dictatorship the exiles try to structure platforms of opposition to demolish it. In them the will of leadership of the PCE is observed in contrast with its relative isolation of the rest of the exile like of the own Mexican politics.
\end{abstract}

\section{KEYWORDS}

Republican exile. Francoism. Mexico. Spanish Communist Party (PCE)

Desde la Transición el exilio es un objeto de atención historiográfica creciente. Sus connotaciones en la política española del siglo $X X$ aluden a la encrucijada de ruptura que supuso la Guerra Civil. Desde esa atalaya puede observarse la génesis del conflicto, la polarización y el fracaso que diluyeron la ilusión inicial de 1931. Asimismo, ante la segunda derrota de 1939, los exiliados deben afrontar un comprometido papel en la Guerra Mundial. La coyuntura favoreció la consolidación del Nuevo Estado entre cuyas estrategias represivas está el exilio forzoso. Las tendencias totalitarias alentaban una

\footnotetext{
'Este artículo tiene su fundamento en el trabajo de investigación: La dimensión política del exilio republicano. Una aproximación desde la delegación del PCE en México (1939-1956), dirigido por el profesor Dr. Abdón Mateos López en el Departamento de Historia Contemporánea de la UNED.
} 
política de eliminación del proyecto reformista incluyendo fusilamientos, depuración y encarcelamiento. En esta primera fase, el miedo y la represión dificultaron enormemente la oposición interna.

A menudo se ha hecho un análisis utilitarista del exilio dada su ineficacia para derrocar a Franco. Sobre todo por la división interna y la costosa asunción de la derrota. Por supuesto, la longevidad de la dictadura debe relacionarse con otros factores como su personalismo arbitral o su flexibilidad ante la realidad internacional. Por su parte, la continuidad del exilio impulsó la oposición interna desde mitad de los cincuenta y desacreditó al régimen en el exterior. Dos elementos notables que contribuyeron a su inviabilidad después de 1975 y que matizan esa perspectiva crítica. Los partidos y las instituciones exiliados fueron perdiendo relevancia, aunque procuraron mantener un legado simbólico de legitimidad democrática.

Un proceso que en México no se dio en el vacío, sino en un país de intensa relación con España, profundamente transformada con la llegada de los desterrados. A continuación se repasan la vinculación entre exilio vital y político, la acogida mexicana y el lugar ocupado por el PCE en esa densa trama de relaciones.

La relevancia cultural y científica del exilio ha centrado la atención de la mayor parte de los estudios. Sin embargo no es nuevo el interés por precisar la auténtica dimensión de su labor política ${ }^{2}$. Dentro de este campo el análisis interno del PCE, sobre todo de la delegación en México con la dirección, con el país de acogida y con el resto del exilio, constituye un ámbito para estudiar sus rasgos genéricos.

La croriología de este trabajo coincide esencialmente con la primera parte de la dictadura. Este período se subdivide en dos partes. Por un lado, 1939-45, con la manifiesta rivalidad entre Negrín y Prieto. Por otro, 1945-50 con las gestiones ante Naciones Unidas y el aislamiento de Franco. Un período de esperanza en un desenlace favorable en la posguerra, con la creación del Gobierno Giral y la condena en la ONU. Finalmente la internacionalización del régimen en 1953 y el creciente peso de la oposición interior desde 1956 marcan el declive del exilio político ${ }^{3}$.

${ }^{2}$ Entre los trabajos pioneros destacan la obra dirigida por José Luis ABELLÁN, El exilio español de 1939 , 6 vols., Taurus, Madrid, 1976-1978 y el estudio de Patricia FAGEN, Transterrados y ciudadanos: los republicanos españoles en México, FCE, México D.F., 1975. Otras referencias significativas al conjunto de la oposición: HeINE, H.: La oposición política al franquismo, Crítica, Barcelona 1983, ABELLAN, J. L. (dir.): De la Guerra Civil al exilio republicano (1936-1977), Mezquita, Madrid, 1983, TusELL GoMEZ, J.: La oposición democrática al franquismo, Planeta, Barcelona, 1977 y TuSELL, J.; ALTED, A. y MATEOS, A.: La oposición al régimen de Franco. Estado de la cuestión y metodología de investigación, 3 vol., UNED, Madrid, 1990.

${ }^{3}$ Los períodos $1939-1950$ (39-45/45-50), 1950-1962 (50-56/56-62), 1962-1969 y 1969-1977 establecidos por AbelLÁN J. L. en De la guerra civil al exilio republicano, Madrid, Mezquita 1983, págs. 71 a 74 , facilitan una estructura adecuada de interpretación de la historia de la oposición. 
Para la elaboración de este trabajo se ha hecho una exploración exhaustiva del Archivo Histórico del Partido Comunista de España ${ }^{4}$. Una de las secciones más provechosas ha sido Documentos PCE que reúne testimonios producidos por los órganos directivos. Las Publicaciones Periódicas constituyen otra sección de consulta principal para conocer la dinámica de los partidos en el exilio desvelando rivalidades y limitaciones. Por ejemplo, órganos como Nuestra Bandera impreso en México pero completamente controlado por la dirección en la URSS o el semanario España Popular para los militantes de base. Ambas publicaciones contaron con una periodicidad sostenida y un coste editorial que revelan la vocación militante y la capacidad para lograr financiación en un contexto bélico. La atención principal de las secciones PSOE y Artículos se dirige a la figura de Prieto, del que se recogen artículos y declaraciones, cuyo contenido sirve de contrapunto a las posiciones del PCE en México. De la autonomía y discrepancia pública de las distintas agrupaciones socialistas en el exilio, se colige una organización más plural y transparente. Esa recopilación también indica un baremo de selección y conservación de este pensamiento antagonista en la persona de un líder que para ellos encarnaba el mayor obstáculo para una convergencia organizativa y de acción. Las secciones no catalogadas, Emigración Política y Divergencias recogen informes de la actividad de las delegaciones en el exilio y de su relación con la dirección. Su interpretación contribuye a comprender el conflicto latente por el liderazgo y el mantenimiento de la ortodoxia. Todos los refugiados padecieron la tensión de conjugar política y vida privada desgajadas abruptamente de su entorno natural. En el caso de los militantes comunistas se añadía una vigilancia sistemática en un contexto diferente al de otros exilios.

El estudio de los documentos revela cómo la dispersión geográfica determina las complejas relaciones entre la dirección en Moscú y los intereses de la Delegación local. La idea de España subyace en la polémica con los socialistas. Las acusaciones mutuas sobre el pasado y la dificultad de una política de Unión Nacional a menudo basculan sobre conceptos nacionales y forma de Estado. Dentro de la política del partido se ha seguido la continua y temprana vocación por la actividad en el interior que explica su importancia final en la historia de la oposición.

\footnotetext{
${ }^{4}$ En el Catálogo del AHPCE editado por Victoria Ramos se explica: «El Archivo Histórico del Partido Comunista de España se creó en 1980, (...) para de esta forma contribuir a la recuperación de la memoria histórica de la sociedad española". El partido no obtuvo en 1977 un resultado acorde con la expectativas, de ahi su interés en poner en valor su pasado.
} 


\section{EL EXILIO COMO EXPERIENCIA VITAL}

Somos un canal en el tiempo que no va a ninguna parte ${ }^{5}$

El conflicto identitario del exiliado nace de la obsesión por la España perdida y la imperiosa necesidad de arraigo. Un desajuste pronunciado por la dura asunción del carácter permanente del destierro. La merma de protagonismo político potenció su implicación en las sociedades de destino agudizando su desclasamiento temporal. Domina un sentimiento contradictorio: el anhelo insatisfecho del retorno y la «muerte lenta» de la nostalgia. Una prisión con puertas y ventanas que impide vivir el presente atrapando al refugiado entre el pasado y el futuro ${ }^{6}$. En sus inicios predomina una sensación de dolor y pérdida:

Duele lo que no se tiene. Todo son muñones: quieres coger las cosas con la mano que te falta. Siempre faltan manos $^{7}$.

El neologismo transterrado implica el transplante de las propias raíces en una tierra común. Esta definición tiene sus límites. La acogida mexicana facilita su percepción como segunda patria. Sin embargo, las dificultades de adaptación y el carácter forzoso de la migración perfilan una lectura optimista $^{8}$. Las segundas generaciones tuvieron que superar el no ser. ni españoles ni mexicanos y acabar siendo un híbrido. La aclimatación fue el resultado del encuentro entre un concepto republicano de lo español y un momento específico de la historia mexicana. Dos identidades convulsas pero complementarias ${ }^{9}$. Imágenes como Numancia Errante o España Peregrina evocan un esfuerzo por identificar el exilio con España. Una concepción del ideal republicano en contra de la patrimonialización franquista de los símbolos nacionales. Una clara continuidad en el discurso de comparación entre 1936 y 1808. Frente a la retórica imperialista del régimen una conciencia representativa, un depósito de legitimidad para el futuro.

\section{EL EXILIO POLÍTICO EN MÉXICO}

El fenómeno del destierro no es ajeno a la tradición contemporánea española. Lo extraordinario de 1939 son unas magnitudes que se aproximan al

\footnotetext{
${ }^{5}$ Una definición rica en matices de la experiencia vital de los desterrados puede hallarse en SÁNCHEZ VÁzquEz, A.: Del exilio. Recuerdos y reflexiones. Grijalbo, México, 1991, págs. 34-38.

${ }^{7}$ Aub, M.: Diarios (1939-1972), Edición M. Aznar Soler, Alba, Barcelona, 1998, pág. 40, [15-XII-1939]

${ }^{8}$ Idea del discípulo de Ortega José Gaos que puede verse en: «La adaptación de un español a la sociedad hispanoamericana» en Revista de Occidente, 38, Mayo 1966, págs. 168-178.

${ }^{9}$ LIDA, C. E.: Inmigración y exilio: reflexiones sobre el caso español, Siglo XXI, México, 1997 pág. 119 , recoge un juego de palabras que sintetiza las dificultades originadas por las diferencias culturales: «En México, o te aclimatas o te aclimueres".
} 
medio millón de desplazados por las fronteras pirenaicas. Aproximadamente la mitad retornó ante una situación precaria y la tenue perspectiva de escapar a las represalias. Esto significó el mantenimiento de un enorme contingente atrapado en el sur de Francia en vísperas de la ocupación nazi. La opinión pública francesa recelaba del carácter presuntamente revolucionario de los españoles. Los campos de concentración alambrados y vigilados por tropas coloniales fueron no sólo una experiencia terrible sino también una humillación de "un país que creíamos amigo " ${ }^{10}$. Esta percepción cambió tras 1945 debido a la participación en la resistencia defendiendo valores comunes. En ese momento, la posibilidad de emigrar a América constituía una alternativa casi utópica. Sin embargo las dificultades económicas y bélicas impidieron una evacuación masiva. La acogida solía ser limitada en cantidad y restringida a personalidades relevantes.

Tras la derrota, la iniciativa política está marcada por la fractura institucional derivada de la dimisión de Azaña. El reconocimiento de la continuidad del gobierno Negrín se convirtió en un elemento de división interna. Ante la victoria aliada, los republicanos hicieron un esfuerzo de acercamiento del que surgió la reunión de Cortes en México y la formación del llamado gobierno de la esperanza. La condena del franquismo en Naciones Unidas en junio de 1945 abrió un lapso de aislamiento liquidado claramente desde 1953. La condena se hizo a propuesta de la delegación mexicana presidida por Luis Quintanilla en el contexto de las conferencias fundacionales de San Francisco ${ }^{11}$. La condena de la Asamblea General del 13 de noviembre de 1946 fue revocada el 4 de noviembre de 1950. La Guerra Fría hizo más importante el factor estratégico de España que su antigua amistad con el Eje. Este revés dejó la recuperación institucional reducida a un valor casi residual. Trasladado el gobierno desde México a París en 1946, se sucedieron distintas estrategias diplomáticas ${ }^{12}$. Una de las más polémicas fue el acercamiento de socialistas y monárquicos.

Varios factores hicieron de México el país del exilio por excelencia, más que por su cantidad, por su variedad e incidencia en la cultura local. No se trata de un exilio exclusivamente intelectual, pero sí existieron criterios de selección política para la inmigración. La reticencia de muchos recién llegados a declarar sobre su filiación política revela la existencia de estos filtros

${ }^{10}$ Cita de Martín Casas, J. y Carvajal Urquijo, P.: El exilio español (1936-1978), Planeta, Barcelona, 2002, pág. 58. Sobre los españoles en Francia: Dreyfus-ARMAND, G.: El exilio de los republicanos españoles en Francia, Crítica, 2000.

1 Se rechazaba la admisión en la ONU de «aquellos Estados cuyos regímenes han sido establecido con la ayuda de fuerzas militares pertenecientes a los paises que han hecho la guerra contra las Naciones Unidas, mientras que tales regímenes estén en el poder . A esta repulsa del 19 de junio se sumó la importante declaración de los tres grandes de dos de agosto en Potsdam.

${ }^{12}$ Sobre las instituciones pueden verse ALTED VIGIL, A.: El Archivo de la II República española en el exilio, 1945-77 (Inventario del Fondo París), FUE, Madrid, 1993, VALLE, J. M. del: Las instituciones de la República española en el exilio, Ruedo lbérico, 1976 y CABEZA-SÁnCHEZ ALBORNOZ, S.: Historia política de la Segunda República en el exilio, FUE, Madrid. 
en los organismos de ayuda ${ }^{13}$. Algo que ocasionó división entre formaciones y resentimiento en los individuos.

México se hallaba inmerso durante el sexenio de Lázaro Cárdenas (19341940) en un proceso de institucionalización revolucionaria, apoyándose en la izquierda sindical de la CTM. El avance de la reforma agraria junto a la nacionalización del petróleo definían los perfiles de este programa. Hay que tener en cuenta que la identidad mexicana se construyó con voluntad de independencia. Los republicanos se hacen símbolo de una España nueva en la Nueva España ${ }^{14}$. De ahí la identificación con la República amenazada en el 36 y asilada en 1939. A su vez la diplomacia franquista es percibida como amenaza a la soberanía nacional dada su cercanía al Eje. La prohibición en abril de 1939 de la filial de FET-JONS en México rechazó esas pretensiones ${ }^{15}$. Dicha proximidad al Eje incrementó la identificación de estas tendencias con la amenaza nazi sobre América ${ }^{16}$. La presión franquista en México no cejó nunca del todo aunque sin conseguir el reconocimiento oficial ${ }^{17}$.

En buena medida el rechazo a los refugiados españoles proviene de su afinidad personal con Cárdenas ${ }^{18}$. La identidad nacional de 1821 se cimentó en un indigenismo superficial y en un sentimiento de mexicanidad crítico con lo español ${ }^{19}$. Otro argumento utilizado en contra de los refugiados es la competencia desleal en el mercado de trabajo y por la capacitación de los recién llegados. Para complicar aún más este binomio entra en juego un tercer elemento muy importante: la antigua colonia española crítica con lo

${ }^{13}$ Sobre la necesidad de profundizar en la existencia y alcance de estos criterios de selección puede consultarse Dumínguez Prats, P.: Voces del exilio: mujeres españolas en México 1939-1950, Comunidad de Madrid / UCM, Madrid 1994, pág. 99.

${ }^{14}$ Este juego de palabras del presidente Ávila en un homenaje de 1943 está recogido por Gordón Ordás, F. en Mi política fuera de España. Talleres gráficos Victoria, México, 1967, pág. 536: «En vuestro viaje a lo que fuera la Nueva España, os sentíais animados por el orgullo de haber dedicado lo mejor de vuestra energía a la construcción de una España nueva. Era natural que este México independiente que siempre ofrece clara acogida a toda auténtica independencia-os recibiera con efusión". Un ejemplo destacado de la solidaridad mexicana previa en PLA BRUGAT, D.: Los niños de Morelia: un estudio sobre los primeros refugiados españoles en México. INAH, México 1985.

${ }^{15}$ Sobre la expulsión de falangistas y la presión de las autoridades locales para evitar el crecimiento de un fascismo local, pueden consultarse PARDO SANZ, R. M.: ;Con Franco hacia el Imperio! La política exterior española en América Latina, 1939- 1945, UNED, 1995, pág. 81 y EscuDERo, M. A.: «Las relaciones entre los exiliados republicanos y la antigua colonia residente en México" en TUSELL, J.; ALTED, A. y MATEOS, A: La oposición al régimen de Franco. Estado de la cuestión y metodología de investigación, 3 vol., UNED, Madrid, 1990, págs. 297 a 306.

${ }^{16}$ Un estudio pormenorizado de la evolución del hispanismo en la relación entre España y México en el siglo XX en PÉREZ MONFORT, R.: Hispanismo y Falange: los sueños imperiales de la derecha española en México, FCE, México, 1992.

${ }^{17}$ En ello profundiza: LIDA, C. E. (comp.): México y España en el primer franquismo 1939-1950. Rupturas formales, relaciones oficiosas, El Colegio de México, México, 2001.

${ }^{18} \mathrm{El}$ mandato de Cárdenas culmina el periodo posrevolucionario y define un eje del tiempo presente mexicano, siendo un elemento clave de su conciencia histórica reciente. Este argumento se desarrolla en MATEOS, A.: «España desde México. Historiografía reciente sobre las relaciones hispano-mexicanas durante la primera mitad del siglo XX» en Historia del Presente, Madrid, 1 (2002), págs. 116-121.

${ }^{19}$ El testimonio de SÁNCHEZ VÁzQUez, A.: Del exilio en México: recuerdos y reflexiones, Grijalbo, México, 1991, en págs. 18-19 confirma esta idea: «Por lo que ha mi toca, lo que yo sabía de México era muy poco, 
que se llamaba invasión de elementos que con el tiempo serán nocivos, peligrosos para México, y que ya empiezan a serlo ${ }^{20}$. Este recelo por su carácter revolucionario y por la hispanofobia propia del nacionalismo mexicano se suman al recuerdo de una violencia aún cercana:

Los años turbulentos habían quedado atrás, pero constituían un ayer inmediato. Los mexicanos de aquel tiempo - los talludos y los más jóvenes - poseían recuerdos personales aún frescos de la época de la violencia ${ }^{21}$.

Las sucesivas expediciones (Sinaia, Ipanema, Mexique...) contenían el embrión intelectual y político del conjunto final. La evacuación y el arraigo inmediato fueron impulsados por los organismos republicanos en colaboración con las autoridades mexicanas. La división SERE-JARE prolongaba la crisis institucional 1939-1945 a través de la enemistad personal Negrín-Prieto que simboliza la tendencia al caudillismo de la emigración. Las acusaciones fueron permanentes. El origen de los fondos de la JARE, el polémico control del Vita por Prieto, favoreció las acusaciones de corrupción y favoritismo de sus adversarios. Se consiguió el desarrollo de iniciativas empresariales, culturales y educativas mientras duró el activo, pero no se disipó el enfrentamiento. Más que por la veracidad de los cargos, por la opacidad y la actitud combativa de la JARE en contra de sus rivales en el México del primer exilio. A pesar del liderazgo de Prieto, la fragmentación fue la tónica dominante como demuestra la existencia de fracciones minoritarias ${ }^{22}$. El acercamiento de los republicanos al sector prietista (Alianza Republicana Española, 1940) permitió a diversas personalidades

\footnotetext{
si excluimos (sic) la visión triunfalista que de su conquista me habian dado los textos de bachillerato (...) México era un país desconocido que vagamente se asociaba a dos nombres tan contrapuestos como Hernán Cortés y Pancho Villa". Por su parte FAGEN W. P. en Transterrados y ciudadanos: los republicanos españoles en México, FCE, México D.F., 1975, pág. 46 comenta el mismo desconocimiento desde México: «La mayoría de los mexicanos sabía de España lo que se les había enseñado en la escuelas primaria y secundaria (...) Los españoles eran, asi, tratados históricamente como conquistadores, no como patriotas fundadores de la nación mexicana».

${ }^{20}$ Cita del 4 de julio de 1939 en el diario La Prensa tomada de CAUDET, F.: Hipótesis sobre el exilio republicano de 1939, Madrid, FUE, 1997, pág. 199. La ayuda estaba condicionada por criterios internos de selección y por el deseo mexicano de despolitizarla. En palabras de Carlos Esplá: "Tuve también el deseo de que la JARE tuviese otras funciones además de las administrativas, pero me he rendido a la evidencia de que no se puede hacer otra cosa, pues los compromisos adquiridos entre Francia y México obligan a la JARE a apartarse de cualquier función política", extracto de una carta de 1941 reproducida en ANGOSTO, P. L.: Sueño y pesadilla del republicanismo español. Carlos Esplá: una biografía política, Biblioteca Nueva Asociación Manuel Azaña, Madrid, 2001, pág. 341.

${ }^{21}$ En Reyes Nevares, S.: «México en 1939» en AbelláN, J. L.: El exilio español..., op. cit., pág. 58. Para profundizar en la inserción de los españoles en ese período mexicano véanse: MATEOS, A.: "España desde México. Historiografía recientes sobre las relaciones hispano-mexicanas durante la primera mitad del siglo XX» en Historia del Presente, 1 (2002). Madrid, págs. 116-121, ABELLÁN, J. L (dir.): El exilio español en México (1939-1982), Salvat, FCE, México, 1982 y LiDA, C. E.: Inmigración y exilio: reflexiones sobre el caso español, Siglo XXI, México, 1997.

${ }^{22}$ Como el Círculo Jaime Vera de orientación negrinista. Una visión del PSOE en México en GILLESPIE, R.: Historia del Partido Socialista Obrero Español, Alianza, Madrid, 1991,Cáp. 2 «Espectadores de la Historia: los exiliados», 71-151.
} 
republicanas como Martínez Barrio, Albornoz y, sobre todo, Carlos Esplá crear una plataforma común. De ahí surgió la Junta Española de Liberación (1943) que excluía a los comunistas. La aproximación de Prieto a sectores monárquicos perjudicó esa convergencia. De hecho los mismos republicanos tuvieron dificultades para mantener la unidad. Izquierda Republicana se situaba en torno al Ateneo Salmerón mientras Martínez Barrio y Gordón organizaron Unión Republicana.

Suele señalarse el declive de la actividad del exilio político tras la fase inicial. La actividad cultural no anuló la militancia sino que la puso en una dimensión menor ante la importancia que adquirió la clandestinidad. Aún así, México fue siempre un centro de referencia cualitativa de la oposición: por la relevancia de sus exiliados y por la continuidad del apoyo oficial.

\section{LA DELEGACIÓN DEL PCE EN MÉXICO}

La intrahistoria de la Delegación viene condicionada por su dependencia de la dirección en Moscú, limitada a su vez por la acogida soviética. Las dificultades para ser admitidos en otros países favorecieron un exilio de cuadros y jefes militares del PCE en la URSS ${ }^{23}$. La invasión nazi trastornó por completo sus condiciones de existencia hasta entonces aceptables. Muchos de ellos lucharon en la contienda y otros acabaron abandonando el país para buscar acomodo en otras zonas de Europa y América ${ }^{24}$. La acogida de la Rusia revolucionaria a los comunistas españoles tiene raíces históricas en la guerra de España. La URSS se presentó como aliado solidario de la Republica amenazada. Esta ayuda militar originó un tópico en torno al oro de Moscú. Desde luego el internacionalismo soviético no era altruista, sin embargo resulta una exageración concluir que la relevancia del PCE del momento hubiera permitido a la URSS controlar España como un satélite ${ }^{25}$.

La influencia del estalinismo en el PCE es una clave esencial para comprender su ideologia y praxis política. Los comunistas españoles tenían poco margen de maniobra, agradecidos por la acogida pero sometidos a idéntico rigor que la población local. La posibilidad de desarrollar políticas autónomas adaptadas a la realidad local y a la pluralidad de su exilio era muy escasa desde México. La muerte de Stalin en 1953 y las consecuencias

${ }^{23}$ La expedición que partió de L'Havre en mayo de 1939 condujo a unos mil militantes y familiares. La selección elitista generó decepción en miembros de base que compartían con los demás refugiados las duras condiciones de internamiento en Francia

${ }^{24}$ La experiencia def retorno a España resultó demasiado brusca para los que la intentaron. Entre las bajas españolas pueden reseñarse el hijo de Margarita Nelken, Santiago de Paul Nelken caído con veinte años en 1945 o el hijo de Pasionaria, Rubén Ruiz, de la misma edad, que murió en Stalingrado en 1942.

${ }_{25}$ Para anotar la retórica de Stalin y el convencimiento de Dolores lbárruri de su naturaleza humanitaria y progresista puede verse SMYTH, D.: «Estamos con vosotros'; Solidaridad y egoísmo en la política soviética hacia la España Republicana, 1936-1939» en Preston, P.: La República asediada, Península, Barcelona, 2001, págs. 158 y 159. 
del XX Congreso cambiaron la dependencia pero no la hicieron desaparecer. Así, los materiales soviéticos constituían aún marco de referencia. El argumento de autoridad personal cedió al colectivo en el contexto de Guerra Fría. La validez del discurso de los líderes españoles se valoraba en función de su acomodo a las directrices del campo socialista y de su rechazo de los postulados occidentales. Se ponía así en función una directriz implícita para el diálogo con los otros grupos instalados ${ }^{26}$. Se trata de documentos orientados a diagnosticar los problemas de la organización en México donde estas referencias no encajan más que como refuerzo de las relaciones jerárquicas.

Los problemas internos contrastaban con el llamamiento exterior a la unidad y con la proclamada disciplina interna. Toda disidencia o dificultad se presenta como un elemento ajeno al partido, propio de la labor divisoria y traidora de algunos militantes. La disolución de la Internacional Comunista en junio de 1943 era una oportunidad para el trabajo unitario y una forma de evitar que la III Internacional apareciese a los ojos de sus enemigos como "un instrumento del gobierno soviético en los países extranjeros»"27.

En México esa relación con la dirección se traducía en una dinámica continua de sanción, control y arbitraje. En un proceso de renovación constante se creó en 1953 un Comité de México del PCE. Debía dirigir el trabajo del partido suprimiendo el órgano de coordinación allí radicado de alcance continental. Se instó a una elección democrática por parte de los miembros residentes del partido. La recriminación básica fue no atender a las orientaciones del partido y de la URSS en la vida interna y en la relación con los demás grupos. La introducción de políticas globales para solucionar el problema de España era una pauta marcada desde arriba. Una de las líneas en que más se insistió fue la Unión Nacional impulsada a raíz de la invasión de la URSS. Esto les alejaba de los postulados de estricta defensa de la legalidad republicana. El partido dio un giro: de ignorar la guerra imperialista y defender el pacto germano-soviético pasó a promover la alianza con las potencias occidentales. Esta revolución programática se impuso a los miembros de la emigración ${ }^{28}$. A pesar de la extinción de la consigna de unidad nacional en junio de 1945, esta premisa había dado lugar en 1943 a la polémica Junta Suprema de Unión Nacional, procurando formar un órgano cen-

\footnotetext{
${ }^{26}$ "Conclusiones de la discusión del Documento de París del exilio acerca de la respuesta al interior», México 26 de marzo de 1957. Delegación del C.C. para América, p.3. AHPCE, Fondos No Catalogados. Emigración Política. Caja B. Jacq 85-86.

${ }_{27}$ «La disolución de la lli Internacional y su repercusión en España», Mundo Obrero, junio de 1943, p.6. AHPCE. Publicaciones Periódicas.

${ }^{28}$ Esto se verifica en diversos lugares como «Unión Nacional» Folleto, 16 págs. Agosto de 1941. AHPCE. Documentos PCE. Carpeta 22. (1941). O en artículos de Nuestra Bandera: «Hagamos de toda España un gran frente contra Franco y contra Hitler», editorial, p.1-12 del Año II, n. 8-9, agosto-septiembre de 1941; «El pacto anglo-soviético golpe aplastante para Hitler» por Palme Dutt, p. 138 del Año II, n.6, de 1941; «Manifiesto del PCE, del PSUC y de la Federación de JSU de España” págs. 22-28 del Año II, n.6 de 1941.
} 
tral en el interior con un amplio espectro de fuerzas. EI PCE en México había procurado un entendimiento con la exclusión de Miaja y Prieto a través de Margarita Nelken. La suma de socialistas y ugetistas fieles a Negrín y de algunos republicanos dio lugar a la Unión Democrática Española (UDE) en 1942. El brusco cambio perjudicó esta iniciativa aunque favoreció la actividad política del exilio mexicano ${ }^{29}$. El período de la Segunda Guerra Mundial también se caracteriza en el PCE por el militarismo. La lucha de unos seis mil guerrilleros acabó con la detención o la muerte de un porcentaje significativo. La estrategia tuvo su auge entre el verano de 1944 y octubre de 1948 decayendo paulatinamente. Los testimonios de los guerrilleros reflejan a menudo el contraste entre una situación idealizada en la propaganda y una realidad interior bien distinta. La represión había dificultado enormemente un levantamiento popular que sólo era una proyección irreal.

La incorporación de las directrices del exterior y el conflicto interno dominan la vida organizativa de los comunistas españoles en México. El primer congreso del partido en el exilio tuvo lugar clandestinamente en Praga (1954). La historia oficial describe el $\mathrm{V}$ Congreso como representativo de la unidad monolítica del Partido. Esa versión expone una visión optimista, ya que hubo que esperar dieciocho años para llevarse a término. La incorporación de la crítica del XX Congreso del PCUS parecía un hecho. Se reconocieron las repercusiones negativas del culto a la personalidad. Los conflictos internos permanecían bajo esta retórica. El representante de la organización en México relata la oposición existente a los métodos autoritarios y antidemocráticos del Comité Central. Los contactos que mantuvieron Adolfo Sánchez Vázquez y Fernando Claudín en París en 1957 tratan sobre el distanciamiento progresivo entre los comunistas en México y el Buró Político ${ }^{30}$.

Las relaciones jerárquicas entre la dirección y la delegación de México puede analizarse también a través de los procesos de depuración. Uno de los más conocidos es el caso del ex ministro Jesús Hernández. Las desavenencias con la nueva dirección acerca de la presencia en la URSS o bien por diferencias personales $u$ orgánicas, tienen relevancia porque explican las tensiones en la elite del partido que también llegan a México. El suicidio de José Díaz en de 1942 generó un vacío que no se cubrió sin polémica. La posición de Hernández como representante ante la IC le animó a postularse como sucesor. En esta lucha por el poder se desataron acusaciones verti-

\footnotetext{
${ }^{29}$ Mateos López, A.: "La embajada oficiosa de Indalecio Prieto durante la presidencia de Lázaro Cárdenas" en Revista de Indias, n.228, (2003).

${ }^{30}$ El abandono de las tareas directivas de Adolfo Sánchez es presentado como el resultado de esta dialéctica: "El conflicto se resolvió de acuerdo con la aplicación habitual de las reglas del centralismo democrático: sometimiento incondicional de la organización inferior al centro. En este conflicto estaban ya, in nuce, todos los problemas — dogmatismo, autoritarismo, centralismo, exclusión de la democracia interna, etcétera» que reclamaban una solución nueva en el movimiento comunista mundial.». Testimonio de Sánchez Vázquez, A. , op cit., pág. 69. La versión oficial puede verse en PARTIDO COMUNISTA DE ESPAÑA: Historia del Partido Comunista de España. Éditions Sociales, París 1960, págs. 249 a 269.
} 
das en su mayoría en torno a la relación Ibárrruri-Antón. Hubo una competencia cerrada para acceder a los resortes de poder y a los privilegios. El proceso de expulsión de Jesús Hernández y Enrique Castro en 1944 se analiza más adelante como parte de la distorsión generada en la delegación en México. Esta exclusión produce un refuerzo de la autoridad central que se ve favorecida por las adhesiones de los militantes más críticos ${ }^{31}$.

La actividad de los comunistas españoles en México tuvo un carácter progresivo en función de las necesidades del partido ${ }^{32}$. Las directrices exigían informar a Moscú trimestralmente y por escrito sobre la actividad y la línea editorial. Los fondos debían repartirse de modo desigual. Las tres cuartas partes para el trabajo en España y el resto para el mantenimiento del aparato. La consideración de España Popular como publicación orgánica se añadía a la necesidad de crear publicaciones nuevas para la UDE o usar la prensa de los partidos americanos ${ }^{33}$.

En 1940 la dirección se plantea conformar un secretariado encabezado por Vicente Uribe. En él, Hernández se encargaría de la propaganda, Carrillo de juventud, Mije de la relación con otras fuerzas, Antón de cuestiones organizativas y Comorera de las relaciones con el PSUC. Sin embargo este primer proyecto no se consolidó totalmente. Uribe, ex ministro de Largo y Negrín, apoyaba su liderazgo en Antonio Mije - evacuado de Francia a finales de 1939-. Este dúo permaneció en México hasta su traslado a Francia en $1946^{34}$. No es el caso de otros dirigentes como Carrillo y Antón cuya movilidad servía para ejercer una labor de comisariado político para América.

Una revisión de las disidencias y expulsiones puede servir como hilo conductor de la dinámica interna. De ella se deduce la dificultad para mantener cohesionado el grupo dentro de las directrices marcadas. La autoridad de la dirección en Moscú se ejercía para mantener una imagen externa de disciplina inalterable. Uno de los primeros casos notables fue el de Margarita Nelken, acusada con los cargos habituales: enemiga del partido y del pueblo, sabotaje a la política de Unión Nacional, calumnia a la dirección, des-

\footnotetext{
${ }^{31}$ La descalificación como traidor interesado es una forma de cohesionar la estructura a través de la depuración interna. En este sentido puede leerse la «Declaración de la Delegación del PCE en Madrid» 21 de julio de 1944, pág. 1. AHPCE. Fondos no catalogados. Divergencias. Resoluciones. Carpeta 1/4: «Como nuestro gran Stalin nos enseñó: el Partido se fortalece depurándose de los elementos oportunistas".

${ }^{32} \mathrm{La}$ "sorprendente inactividad política" contrastaba con la cohesión y activismo del partido en la primavera y el verano de 1939. Algunos autores explican el silencio como una justificación del pacto germano-soviético. Véase RuBio, J: La emigración de la Guerra Civil de 1936-1939. Historia del éxodo que se produce con el fin de la I/ República Española, 3 vol., Editorial San Martín, Madrid, 1977, pág. 505.

${ }^{33}$ Este proyecto organizativo se detalla en el Manuscrito "Sobre la dirección en América». AHPCE. Documentos PCE. Carpeta 21 (1940).

${ }^{34}$ A partir de esta fecha y hasta la ilegalización del PC en Francia en 1950 prosiguen en la primera línea de enfrentamientos por la dirección. Básicamente en competencia con Antón y Carrillo. Mientras éstos permanecen en la clandestinidad de París, Uribe y Mije junto a Enrique Líster se instalan en Praga. Si la figura de Carrillo creció en importancia Francisco Antón pasó a un segundo plano tras su distanciamiento de Dolores Ibárruri.
} 
precio a la clase obrera, división y difamación. El cargo más grave es el intento de crear una corriente en un partido tan celoso de su unidad, fortaleza y disciplina ${ }^{35}$.

La organización para América se vio trastocada por la muerte de Pedro Checa en 1942. Este hecho instó a restablecer un mecanismo más fluido de contacto entre México y Moscú, reforzando la estructura propuesta en 1940. La reunión del C. C. de 1943 fijó esta necesidad recordando además los principios de proximidad a Negrín ${ }^{36}$.

El aludido caso Jesús Hernández simboliza, junto al proceso contra Enrique Castro, un punto álgido dentro del proceso de depuración interna. Hernández fue enviado a México en el verano de 1943 bajo la vigilancia de Antón. La acusación de reproducir la lucha por el poder en México determinó su expulsión final en mayo de 1944 siendo presentado como titista, contrario a la unidad del partido y traidor. La discusión se tiñó de aspectos personales que se prolongaron en México reproduciendo el enfrentamiento con Uribe y Mije. Sus escritos señalan con crudeza las deficiencias internas. Algo que contrasta vivamente con la retórica sobre la unidad. La presión obligó a su compañero Enrique Castro a reconocer que había sido influido por él para trabajar contra la unidad del partido ${ }^{37}$.

La defensa que establece trató de subrayar las contradicciones entre las ideas y praxis. Denunció la inconsistencia del negrinismo contradictorio. Criticó también con dureza la vida diaria en el seno de la Delegación:

«En toda la república mejicana no sobrepasaran el número de 800 los militantes que tenemos. De ellos más de 150 han sido expulsado (sic) del Partido. Se excluye a la gente por las cosas más nimias y con la mayor naturalidad. Coincide todo esto con el hecho de que la mayoría de los viejos cuadros del Partido (...) están relegados, en tanto que toda una serie de militantes que nadie sabe de quienes son ni cuando han llegado al Partido, son los funcionarios y hombres de confianza dde (sic) la Delegación del C.C. en México. (...) Enmarcado en esta situación nos encontramos con un ambiente increíble de corrupción en la esfera superior del Partido. El Partido vive minado y corroído por un malestar que encuentra su desahogo en críticas acerbas a la Delegación del Partido» ${ }^{38}$.

El ataque contra Uribe se ciñó al lujo de su vida personal contrastado con las penalidades que atravesaba México y especialmente los refugiados. Eso

\footnotetext{
35 «Resolución Margarita Nelken». Publicado en España Popular el 23 de octubre de 1942. AHPCE. Documentos del PCE. Carpeta 23 (1942), pág. 1.

${ }^{36}$ «Documento de trabajo" julio de 1943. AHPCE. Documentos PCE. Carpeta 24 (1943).

${ }^{37}$ La retractación obligada de Castro puede leerse en «Reunión del C.C.» de 5 de mayo de 1944. AHPCE. Documentos del PCE. Carpeta 25 (1944) págs. 28-29. A pesar de ello Castro es calificado como "obrero desclasado que presume de haber discutido en el Ateneo" en la "Reunión del C.C." de junio de 1944. AHPCE. Documentos del PCE. Carpeta 25 (1944).

${ }^{38}$ «A la delegación del C.C del PC de E. En la Unión Soviética» por Jesús Hernández en México, 2 de abril de 1944. AHPCE. Fondo no catalogado. Divergencias. Correspondencia. Carpeta 1/ 2, pág.. 10.
} 
generó un rechazo que abonó la división interna y el anticomunismo ajeno. Según su versión Uribe y Mije rompían la UDE creyendo que no había «nada que hacer con el resto de la emigración». Espiaron, amenazaron y no soportaron la menor crítica e incluso malversaron. Hernández llegó a reconocer parcialmente su culpa. Sin embargo, Antón y Mije continuaron hasta el punto acusarlo de estar a sueldo de la embajada americana. La condena que le prohibía escribir fue el punto de no retorno. Cansado de no ser tenido en cuenta en el proceso rompió la disciplina con un artículo en España Popular el 20 de marzo de 1944 en el segundo aniversario de la muerte de Díaz. La descalificación por su labor «fraccional» se convirtió en una prueba de la fidelidad a la dirección en Moscú y a la local de México. La resolución se transformó en un acta de adhesión a la URSS a quien cedieron la expulsión $^{39}$. La decisión de segregar a Hernández por parte de la dirección se unió al relevo de Castro de toda tarea ejecutiva. Esta condena fortaleció un modo de actuación disciplinaria encabezada por Uribe en México ${ }^{40}$. La respuesta de Hernández fue una carta a la dirección meses después, donde continua una línea de defensa cimentada en la crítica de las contradicciones de la dirección local. Insistió en que la falta de unidad y el aislamiento de partido procedía de una actitud contraria a los postulados comunistas. Reclamaba que la energía empleada en su difamación, donde se le acusaba de trotskista, se emplease en una labor coherente de unidad de las fuerzas republicanas. Recordaba que su presencia en México respondía a una decisión del partido encaminada a corregir la aplicación de la unión nacional. Denunció el ambiente coactivo de las asambleas que impedían un clima de discusión sincero para sacar adelante el programa de la Junta Suprema. Confrontaba la necesidad de devolver la democracia interna con la acusación de ambición personal y egolatría ${ }^{41}$. Esta denuncia se convirtió en una crítica abierta en la carta manifiesto que Hernández publicaba un año después. En ella se explicitaban con dureza los argumentos utilizados en las comunicaciones internas. Más allá de la coyuntura concreta de la participación en el gobierno Giral incidía en la falta de libertad de los militantes para participar en la vida del partido y en el caudillismo del grupo Uribe-Mije. No decía buscar una crítica de corriente sino una alternativa que favorezca a todos los que han sido injustamente sancionados ${ }^{42}$.

\footnotetext{
${ }^{39}$ En el documento citado anteriormente «A la delegación del C.C del PC de E. En la Unión Soviética» por Jesús Hernández se reproducen tres cartas suyas escritas en México con fecha de 27 de marzo, 2 y 26 de abril de 1944. La descripción del expediente en su contra aporta interesantes matices sobre la dependencia de la delegación respecto de la jerarquía residente en Moscú.

${ }^{40}$ «Resolución del C.C. del PC en Moscú» 6 de mayo de 1944. Fírmada por Dolores lbárruri, Jose. A. Uribes, Modesto, Líster, Segis Álvarez, F. Ortega y otros. AHPCE. Documentos PCE. Carpeta 25 (1944).

${ }^{41}$ «Carta a la dirección del PC en México» Jesús Hernández. México, 15 de junio de 1944. 5 págs. AHPCE. Fondos no catalogados. Divergencias. Correspondencia. Carpeta $1 / 2$.

42 «Carta abierta a todos los afiliados al PCE» por Jesús Hernández. México, 31 de agosto de 1945. AHPCE. Fondos no catalogados. Divergencias. Folletos. Carpeta 1/5.
} 
Esta persecución de la disidencia pervivía en los 50. Los comportamientos individuales que presentaban perfiles de autonomía intelectual o que trataron de imponer una disciplina propia en México terminaban en depuración. Otro de los personajes destacados en la délegación inicial sufrió esta experiencia. En el caso de Joan Comorera se utilizó el nacionalismo como elemento para separarlo acusándolo de forzar la presencia del PSUC en la IC y de dañar las relaciones con el conjunto del PCE. Aunque se encontraba en París el origen de su situación proviene de la marginación a que fue sometido en México a donde había llegado en 1940. El proyecto de República Catalana quedaba limitado por su raíz revolucionaria sin desear una división profunda con el PCE. Comorera trató de reforzar este vínculo eliminando los sectores más próximos al nacionalismo liberal del Consell Nacional de Catalunya. El intento de controlar la autonomía del PSUC es la otra clave para entender estas condiciones adversas que tuvo que afrontar. A pesar de ampliar el secretariado del PSUC en 1943 no logró consolidar su papel como garante del catalanismo de izquierda vinculado al proyecto comunista ${ }^{43}$. Finalmente, su salida determinó su vuelta a España en 1951 donde vivió clandestinamente, fue detenido y encarcelado en 1954 hasta su muerte. La versión oficial del partido fue:

(...) a finales de 1949 Juan Comorera se descubrió como un enemigo que intentaba llevar al PSUC contra el PCE, y transformar el PSUC en un partido de tipo nacionalista burgués ${ }^{44}$.

A comienzos de los 50 un tema recurrente era la eliminación los sectores acusados de titistas. La dirección de Felipe Arconada, Wenceslao Roces y Ricardo Castellote seguían de cerca la influencia de este sector próximo a Hernández. Especialmente la posibilidad de crear un partido con disidentes del círculo Jaime Vera. En el fondo no se toleraba el acercamiento de los militantes a otros sectores republicanos bajo la bandera común del rechazo al estado soviético. La dirección se enfrentó en 1953 a una crítica similar a las que habían presidido la vida interna con anterioridad. Se invocó un esquema de dirección colectiva de "arriba a abajo». Se rechazó el método de la expulsión arbitraria. Se señaló la «conducta errónea y sectaria» seguida con

\footnotetext{
${ }^{43}$ Una reconstrucción del período de asentamiento en América del PCSUC y sus controversias en Martín Ramos, J. L.: Rojos contra Franco. Historia del PSUC, 1939-1947, Edhasa, Barcelona, 2002,Cáp. 2, "La reconstrucción en América», págs. 79-121. Superando los márgenes estrictos de una biografía, se concretan los perfiles de una compleja relación entre nacionalismo catalán y comunismo en la era estalinista en Caminal i Badia, M.: Joan Comorera, Empuries, Barcelona, vol. ll «Guerra i revolució, 1936$1939 "$ (1984) y vol. Ill «Comunisme y i nacionalisme, 1939-1958» (1985).

44 «Datos sobre el PCE» por Fernando Claudín, 7 de septiembre de 1951, pág. 3. AHPCE. Documentos PCE. Carpeta 32 (1951). Un informe más exhaustivo de la biografía de Joan Comorera puede verse en AHPCE. Fondos no catalogados. Divergencias. Joan Comorera, Caja 107. Dentro de ella, en la sección Correspondencia. Carpeta $2 / 3$ hay una carta de Comorera a Uribe fechada en París el 26 de agosto de 1949 donde esboza su defensa.
} 
los cuadros procedentes del PSOE. Tanto a ellos como a los intelectuales se les había sometido a una marginación contraria al fortalecimiento de la unidad republicana y a la voluntad de captación de militantes en otros partidos. El camarada Esteban Vega fue presentado como un déspota con concepciones «antipartido». Las conductas autoritarias fueron calificadas como ajenas a los fundamentos y métodos del PCE, a pesar de que éstas apareciesen reiteradamente en su historia ${ }^{45}$.

En 1954 la directiva de W. Roces y de A. Sánchez se enfrentó a retos análogos. La coordinación para América desde México siguía sin funcionar correctamente. El proceso de captación de socialistas dificultaba la difusión de las políticas unitarias del momento encaminadas «a la paz» frente a al imperialismo. No se trataba de un planteamiento nuevo, ya que asumen el decepcionante resultado cosechado en cerca de veinte años de exilio ${ }^{46}$. El B.P. seguía mediando en los conflictos relacionados con la disciplina y el aislamiento de las bases. El Comité de México se reorganizó distribuyéndose en comisiones sectoriales de propaganda, estudio, organización y finanzas. El partido tenía presencia en los diversos estados en torno a unos veinte grupos pequeños que sumaban unos 422 afiliados ${ }^{47}$.

Aún a la altura de la convocatoria de delegados de 1959 no existía un método aceptado por todos, ni se resolvió claramente un sistema de relaciones con la dirección fuera de México, ni con el resto de los emigrados ${ }^{48}$. Desde un principio, la expulsión de militantes y el autoritarismo de la dirección fueron criticados en las comunicaciones. No obstante, las sucesivas destituciones y relevos impuestas no hicieron desaparecer estas prácticas. Ni siquiera cuando su relevancia política era menor, ya en las inmediaciones de la Transición ${ }^{49}$.

Por lo tanto la jerarquía y la ortodoxia fueron piedra angular. El problema radica en las contradicciones que surgían de su aplicación. En primer lugar, por los vaivenes de la dirección en la URSS. En segunda instancia, por la fácil tentación de los dirigentes locales de convertirse en virreyes autónomos de una jerarquía que había de imponer su autoridad desde otro continente.

\footnotetext{
45 «Resolución sobre el trabajo del partido en México» BP 1953, 4 págs. AHPCE. Documentos del PCE. Carpeta 34 (1953).

${ }^{46}$ «Informe Santiago Gilabert» págs. 8-9. 1954. AHPCE. Emigración Política. Caja 102. Informes de América Latina. 102/6. 2 México.

${ }^{47}$ Sobre el estado del partido en este momento: «Informe de la situación del Partido en México» por Wenceslao Roces, 22 de septiembre de 1954, 7 págs.; «Relación de grupos y militantes», (1954) 5 págs.; «Resolución de pleno de delegados de la organización del PCE en México" de 16 de mayo de 1954, en AHPCE. Emigración Política. Caja 102. Informes de América Latina. 102/6. 2 México y 3 Resoluciones.

${ }^{48}$ En el ambiente está la preparación del VI Congreso (enero de 1960) donde Santiago Carrillo ascendió a la secretaría general.

${ }^{49}$ A modo de ejemplo puede anotarse la expulsión de Caloto y de Ambou en 1973 por los cargos habituales: «labor fraccional, calumnias a los dirigentes, separación de la línea del Partido, campaña sistemática y ponzoñosa de difamación" según consta en el «Comunicado» del Comité de México de 24 de febrero de 1973. AHPCE. Fondo No Catalogado. Emigración política. Caja B. Jacq 534.
} 
En tercero, porque la necesidad de encontrar medios de subsistencia dignos chocaba con la naturaleza de un activismo tan exigente. Además quienes demandaron disciplina, obediencia y fidelidad a los principios marxistas gozaban de privilegios que irritaron a la militancia de base. Enfrente, estos militantes y los líderes de la emigración tenían que buscarse ocupación. A veces, subsistiendo con la ayuda de los organismos republicanos. EI PCE reclamó una eficacia mayor en la distribución de ese apoyo criticando la gestión, sobre todo de la JARE:

Para demostrar el interés de muchos de estos señores, tanto del S.E.R.E. como de la J.A.R.E.; pero principalmente de esta última, en no ayudar a salvar a los refugiados republicanos españoles, como también en no facilitar los medios necesarios para que la nueva emigración española en México pueda tener el concurso económico necesario, a fin de poder subsistir en territorio mexicano, y no verse obligada a atravesar calamidades enormes (...) Es deber nuestro (...) hacer cuantos esfuerzos sean necesarios para incorporarse a la producción, porque no es posible vivir esperando el subsidio, ni que se abran fuentes de trabajo prometidas pero irrealizables ${ }^{50}$.

Conservar su identidad comunista en el exilio mexicano, como minoría, eras muy distinto de hacerlo en la URSS donde resultaba un acto convencional. La dificultad para combinar vida política y privada fue notable. Máxime teniendo en consideración que la mayoría de los refugiados no eran comunistas:

Se debe terminar con esa monstruosa concepción de enjuiciar y calificar al militante por el hecho de tener un automóvil, un pequeño taller o un aparato de televisión. Hay que ser implacables en la lucha contra la corrupción, pero es absolutamente falso el confundir la corrupción con un medio normal y honesto de ganarse la vida 51 .

La dirección fue reconociendo algún progreso como el impulso dado desde México a la política de "España y la Paz" pero siempre criticando la lectura superficial de las consignas. El estilo ordeno y mando fue señalado como una fuente de insatisfacción de la militancia y de lastre para el partido. A esta realidad se oponía una visión mitificada en los textos públicos del carácter del partido. No era deseable mostrar la intensidad de estas carencias mientras se postulaban para liderar la unidad nacional.

Se llevaron a término algunas iniciativas para evitar un fraccionamiento de la organización o el desarrollo de una política propia de los comunistas

50 «Al Servicio del Pueblo Español» por UGT, PCE, PSUC y JSU, México, 10 de diciembre de 1940, págs. 12-13. AHPCE. Documentos del PCE. Film XXI. Ap.250 (1940).

${ }^{51}$ «Resolución sobre el trabajo del Partido en México» del B.P., p.1. AHPCE. Documentos del PCE. Carpeta 34 (1953). 
españoles residentes en México. Entre estas actividades se crearon comités de ayuda a los presos en España, se conformaron asociaciones de mujeres antifascistas o se impulsó, en colaboración con otros republicanos, la Unión de Intelectuales Españoles en México de 1947. Una de las tareas más destacadas fue la producción editorial de la prensa orgánica. España Popular se fundó en febrero de 1940. Este semanario de gran formato estaba destinado a transmitir las noticias y opiniones a la militancia de base. Se ocupaba sobre todo de la situación en España y en la URSS y en menor medida del resto de la emigración en México. Nuestra Bandera se publicó en México entre 1940 y 1945. Esta revista estaba destinada a formar la opinión de las elites de Partido y a fijar la línea oficial. Sus páginas eran consideradas un instrumento idóneo de adoctrinamiento para evitar la dispersión de voces lógica en la diáspora del exilio ${ }^{52}$.

Entre 1949 y 1953 apareció Nuestro Tiempo. Revista Española de Cultura, extensión del proyecto de la Unión de Intelectuales. El objetivo de extender la influencia comunista chocó con algunos prejuicios: la subordinación de la cultura a la política y el peligro de un contacto demasiado estrecho con los no marxistas.

En resumen, la organización se debatió en un diálogo complejo entre la fidelidad orgánica e ideológica y la dificultad de una vida militante en el exilio. La bicefalia entre Moscú y la jefatura local se resolvió con la imposición desde arriba y la apelación a la ortodoxia. En el incumplimiento de ese recetario de lo que era propio del partido, siempre fue la dirección local la que fallaba al marxismo, la que había vejado los derechos de los militantes. Aunque el mayor pecado fuese el fraccionamiento del partido, eran las expulsiones lo que más lo merman. Se promovía que los militantes en México gozaran de un mayor margen de maniobra en la toma de decisiones, pero luego se castigaba al disidente. En realidad, solía premiarse la fidelidad ciega. Como ironizaba Max Aub: «Epitafio del ortodoxo: No abrió el pico" $" 53$.

La historia de la delegación se completa con la análisis de las relaciones que mantuvieron con el resto del exilio en México. La necesidad de convertir la relación con los demás en un instrumento de hegemonía favoreció la creación de plataformas mixtas. En ningún caso la captación o el control de estas iniciativas en beneficio de los intereses comunistas debía realizarse de un modo demasiado explícito. Los resultados no fueron siempre los plantea-

\footnotetext{
${ }^{52}$ Desde la calle Morelos 77 se producía esta edición mensual. Los autores y títulos de los artículos dan idea de su orientación. Por ejemplo: «Para salvar la Paz del pueblo español y acortar los plazos de su victoria» editorial, en Año II, n.3, marzo de 1941, págs. 1-19; «El PCE y la emigración española. Dos años después haber perdido la guerra» por A. Mije en Año II, n.4, abril de 1941, págs.28-43; «Qué es y qué representa la Unión Nacional de los españoles» por V. Uribe en Año IV, n.1, enero 1943, págs. 26-35 y «Llamamiento de la Junta Suprema de Unión Nacional del 12 de septiembre de 1944» en Año V, n.12, 31 diciembre de 1944, págs. 85-86.

${ }^{53}$ AUB, M.: Diarios..., op. cit., p.123, [22 de febrero de 1945].
} 
dos inicialmente, aunque es una característica que comprende todo el periodo analizado:

En este punto, preciso es señalar que, si el balance de trabajo no ofrece mejores resultados, ello se debe a que todavía hay camaradas que no ven con claridad la necesidad de hacer mayores esfuerzos por establecer el diálogo con las organizaciones políticas de la emigración, aprovechando para ello cualquier avance de éstas, por insignificante que sea ${ }^{54}$.

La JSU debe atraer a sus filas y movilizar en sus actividades educativas, culturales, deportivas a la masa de jóvenes antifranquistas residentes en Méjico y en otros países de América Latina ${ }^{55}$.

Sin embargo, ese afán unitario no impide que el aislamiento acabara siendo una de sus principales características. La participación del partido en los gobiernos en el exilio tampoco fue un instrumento preciso para acercarse a los demás grupos. Sólo en 1946 consiguió entrar en el gobierno Giral a través de Carrillo. Posteriormente Uribe participó en el presidido por Llopis. Su apoyo no fue unánime ni siquiera durante su pertenencia a esta institución. Durante el proceso Hernández éste ya denunciaba en 1944 que una unidad sin nosotros podía convertirse en una unidad contra nosotros. La voluntad unitaria explica la evolución de sus posicionamientos respecto a los demás. Así la reticencia con que es vista la Alianza Nacional de Fuerzas Democráticas se transformó progresivamente en una aproximación táctica.

Un elemento que expresa parcialmente el aislamiento es la importancia que concedieron a la actividad en el interior. Los documentos revelan que el PCE consiguió convertirse en un organismo de lucha antifranquista de referencia en este campo gracias a una voluntad muy temprana. La emigración era clave como soporte a través de la financiación, la propaganda y la sustitución de militantes detenidos. Una de las críticas que efectuaron a la ANFD es que centraban su actividad en la diplomacia y no en el «corazón de la resistencia antifranquista» que residía en el interior del país ${ }^{56}$. Los militantes en México encontraban una satisfacción en esta solidaridad como medio de encauzar sus energías en una actividad útil contra el régimen. Para la dirección esta tarea tenía una función pedagógica: demostrar que el PCE era la vanguardia en la reconquista republicana.

La actividad del partido animaba a los militantes a proseguir una lucha cuyo fin aparecía en un horizonte cercano donde les estaba reservado un pa-

\footnotetext{
${ }^{54}$ «Resolución del B.P sobre los problemas de la organización de México» 1-9-1956. AHPCE. Fondo no catalogado. Emigración política. Caja B. Jaq 87. Pág. 2.

${ }_{55}$ «Resolución sobre el trabajo del Partido en México. B.P.» AHPCE. Documentos PCE. Carpeta 34 (1953), pág. 3.

${ }^{56}$ Puede consultarse en la carta que la delegación del C.C envía al presidente del Comité Nacional de la AFD. 13-2-46. AHPCE. Fondos no catalogados. Documentos del PCE. Anexo. Jaq 35.
} 
pel protagonista. Teniendo en cuenta estas premisas no resulta extraño que las relaciones con los demás partidos estuvieran presididas por el desencuentro. Los republicanos consideraron nociva la defensa difusa de los ideales y las instituciones republicanas. La asociación con los comunistas les hubiera resultado aceptable en una situación predemocrática pero nunca como una repetición del Frente Popular en el exilio. En particular por unas pretensiones hegemónicas no justificables en criterios cuantitativos. Es interesante apuntar que la diferencia ideológica se cimentó en su liberalismo, incompatible con quienes consideran al hombre como un esclavo del Estado-Dios ${ }^{57}$. La relación con los anarquistas tampoco fue especialmente amistosa. El carácter apolítico, la pugna durante la Guerra Civil y la situación de los libertarios en la URSS ahondaban este distanciamiento. El contacto con los sectores nacionalistas se enmarca en unas coordenadas similares, ya que la pretensión de atraerlos a las plataformas comunes generó suspicacias. Por ejemplo con la Alianza Nacional de Catalunya, versión regional de la política de unidad nacional. Los postulados de L'Humanitat, órgano de ERC en México eran refutados porque tendían al acuerdo con otras fuerzas ${ }^{58}$.

El sector con el que mantienen una relación más intensa de aproximación y de enfrentamiento fue el socialista. Por un lado, estaba la vieja aspiración del partido único. De otro, el anticomunismo de una parte del PSOE y de UGT, usado como bandera en sus disputas internas. El acceso y la salida de Prieto la cartera de Defensa en el Gobierno Negrín determinaron el inicio de un enfrentamiento particular. El decreto de Prieto de 28 de junio de 1937 prohibiendo la propaganda en el ejército fue indicador significativo. Aunque la querella puede remontarse a la propia fundación del PCE en 1921 como escisión socialista, fue durante los años treinta cuando se fraguó este abismo ideológico y personal. Lo relevante es como esta dinámica afectó a la relación de los comunistas con el resto del exilio y como agravó las tensiones internas del PSOE. El repudio hacia los comunistas estuvo presente incluso en sensibilidades negrinistas que rechazaban la manipulación de la Unión de Intelectuales o los ataques frontales a otras iniciativas como la JEL cuya misión era más cultural que política.

La Asamblea de Toulouse de 1947 reafirmó el distanciamiento con los próximos al Círculo Jaime Vera y la desaprobación de alianzas con los comunistas. El liderazgo de Prieto lo consagra como el enemigo visible del

${ }^{57}$ Gordón Ordás, F: Mi política fuera de España. Talleres gráficos Victoria, México, 1967, pág. 569. Véanse también las págs. 541, 567 y ss. Las palabras de Carlos Esplá resumen el escepticismo con que son recibidos los contactos en pro de la unidad "La actividad de los comunistas y sus amigos, aunque presenta como finalidad la unión de todos, se traduce prácticamente en confusión y desunión. Tienen una tenacidad admirable en su táctica, que consiste en querer unir a los demás a condición de que dejen dirigir por ellos. El sevillano Díaz no era precisamente el vasco Ignacio de Loyola; pero el partido se parece mucho a la orden» en ANGOSTO, P. L.: Op. cit., 2001, pág 362.

58 «Carta abierta del PSUC a Miquel Santaló» por Joan Comorera, México, 15 de febrero de 1943. [En catalán] AHPCE. Documentos del PCE. Carpeta 24 (1943). 
PCE. En torno a él y a Negrín se desataron acusaciones de corrupción y de ineficacia muy graves. Aunque el PCE cargó básicamente contra la JARE, tampoco el SERE se libró de sus críticas. Lo que demuestra la relativa debilidad de su alianza con los negrinistas.

Prieto fue consiguiendo cierta autonomía gracias a la independencia financiera y desde entonces se perfiló como ese alter ego del exilio en México que para la dirección del PCE resultaba intolerable. Toda su actuación posterior encontró el rechazo de este partido. La delegación de México permanecía cerca para anotar sus movimientos y sabotear sus tácticas. El proceso de acercamiento a los monárquicos no hizo sino multiplicar exponencialmente este antagonismo. Aunque posteriormente mantuviera una posición crítica con Don Juan, para los comunistas trabajó siempre por una restauración reaccionaria. El fracaso de la estrategia condujo a Prieto a la dimisión en 1950. La división interna y sus errores de análisis internacional condicionaron el final de su liderazgo. En cualquier caso supusieron explorar una propuesta de transición más allá del modelo de Estado. Para Prieto, ya desde su experiencia durante la guerra, el PCE no era un partido hermano, sino un rival e incluso un enemigo ${ }^{59}$. Para el negrinismo debía pervivir el espíritu frentepopulista. Esta rivalidad, interna y con los comunistas, nació de la competencia por ocupar un espacio político y compartir unas bases ideológicas demasiado próximas para no provocar roces:

Para los comunistas, un socialista es infinitamente más odioso que un capitalista. La propia afinidad produce el fenómeno ${ }^{60}$.

El carácter crítico de Prieto con la URSS, acrecentado por la Guerra Fría, imposibilitó una eventual reconciliación. A su vez, consideró que un acercamiento al PCE iba a dificultar el contacto con las potencias occidentales en el seno de las gestiones antifranquistas. Una esperanza que luego resultaría vana, pero por la que este sector socialista apostó con fuerza. Sin duda toda identidad en conflicto, como es la militancia en el exilio, necesita del otro para afirmarse por oposición. Franco y Falange ocuparon ese papel desde fuera, pero, en el interior del campo republicano, Prieto ocupó el papel estelar. Las iniciativas comunistas buscaban ahondar la fractura interna del PSOE así como desprestigiar a la JARE. En particular por la discriminación de sus afines en los criterios de selección de las ayudas. La acusación más grave presentó a Prieto como un colaborador de Franco entregando cama-

${ }^{59}$ Tusell, J.: La oposición..., op. cit., p. 176. Sobre la importancia en Prieto de mantener la unidad del partido y sus propios postulados en el destierro véase GIBAJA VELÁZOUEZ, J. C.: Indalecio Prieto y el socialismo español (1939-1950), Fundación Pablo iglesias, 1995, págs. 231-232.

${ }^{60}$ « ¿Socialistas y comunistas: continuarán peleándose?» por I. Prieto en Siempre, México, n.116, 14 de Septiembre de 1955, p.1. AHPCE. Emigración Política. Caja 133. Socialistas y sindicalistas. Carpeta 1. 1-2. Dirigentes. 
radas en Francia. Para los que conocieron los campos franceses, asociar un nombre al del embajador Lequerica era el insulto más terrible que se pudiera concebir ${ }^{61}$. Para aceptar a los socialistas, el PCE les puso condiciones como el reconocimiento de su tarea en el interior. En lo referente a su dependencia de la URSS, les irritaba que la propaganda socialista contribuya a presentarlos como fuerza no democrática. Las publicaciones del PSOE, comenzando por Adelante, eran percibidas como instrumentos antagonistas, especialmente de España Popular.

La llamada Delegación de la Ejecutiva del Partido Socialista en México, ha venido publicando un boletín que, desde el título hasta el pie de imprenta, era un vertedero de injurias; de ataques contra los comunistas. Sobre Franco, su régimen y la situación de nuestros compañeros en España, ni una palabra, como si tal problema no existiera ${ }^{62}$.

Ni siquiera con los más próximos como Lamoneda o González Peña hubo una sintonía continuada, sucediéndose alternativamente las simpatías y las críticas. Para comprender esta línea de falla puede apuntarse una razón. La incapacidad del PCE para aceptar la existencia de otras culturas políticas dentro del exilio incompatibles con su visión de la realidad, asumiendo su condición minoritaria. Sobrevaloraron su liderazgo de las masas populares en un análisis optimista acerca de la fortaleza de la dictadura. No tanto por una ingenuidad militante, sino por el deseo de movilizar a las bases.

Sin este reconocimiento de la existencia de otras identidades políticas en el exilio era difícil avanzar en la unidad. Porque, sin duda, la vista estaba puesta en España, pero con frecuencia más en su pasado que en su presente. Dicho déficit no fue exclusivo de este partido, pero vino agravado en esta época por su reticencia a los valores socialdemócratas y liberales dominantes en las demás fuerzas radicadas en México. Desde esta perspectiva para acercarse al otro y encontrar su cooperación había primero que conocer su forma de ser:

Naturalmente un socialista, un republicano o un liberal tiene de la política una concepción distinta de la nuestra. Para ellos renunciar a ser jefes, ministros, gobernadores no es poca cosa. Y nuestro deber es comprender su mentalidad, su educación y hasta sus ambiciones, pues da la casualidad de que así piensan todos, y que todos ellos son jefes, ministros y gobernadores y los que no lo han sido o lo son, piensan serlo ${ }^{63}$.

\footnotetext{
${ }^{61}$ Véase «Al Servicio del Pueblo Español» por UGT, PCE, PSUC Y JSU, México, 10 de diciembre de 1940. AHPCE. Documentos del PCE. Film XXI. Ap. 250. (1940). Sobre una denuncia concreta puede consultarse ANGosto VÉlEZ, P. L.: SUeño..., op. cit., p.340.

${ }_{62}$ «La socialdemocracia española y la realidad política actual de España» por A. Mije, Nuestra Bandera, Año I, n.4-5, octubre de 1940, p.70. AHPCE. Publicaciones Periódicas.

${ }_{83}$ «A la delegación del C. C. del P. C. de E. en la U. S.» Carta de Jesús Hernández, México, 27 de marzo de 1944. AHPCE. Fondos No Catalogados. Divergencias. Correspondencia. Carpeta 1/2.
} 
Por otra parte, tras estas querellas afloraron distintas maneras de concebir la idea de España. La hispanidad de América y el carácter americano de España hicieron del exilio en México un lugar donde reflexionar esta utopía, este redescubrimiento de España. Desde el principio los exiliados fueron conscientes de que conformaban un modelo a escala del país. Lo que en la cultura gozaba de cierto acuerdo en torno a los valores republicanos era más difícil de compartir en cuestiones estrictamente políticas. El problema radicaba en precisar ese concepto. En cuanto al modelo de Estado el común denominador era la defensa del sistema republicano. No obstante, cuando se trató de establecer contacto con sectores no republicanos moderados se agravaron las disensiones. Respecto a las nacionalidades, al PCE le preocupó especialmente que las plataformas unitarias se transformaran en instrumentos de reivindicación nacionalista de tipo liberal. La principal atención giró en torno al PSUC. EI PSUC compartía con el PCE su rechazo de la socialdemocracia o la gratitud por la solidaridad soviética pero quedaba un remanente de tensión acerca de si eran una filial o un partido independiente.

La rivalidad con Prieto encuentra aquí otro espacio propicio para desarrollarse. Habitualmente era acusado por su españolismo como concepto incompatible con el internacionalismo socialista. Su defensa de la superioridad del Estado como expresión de la voluntad nacional chocaba frontalmente con la omnipresencia de lo colectivo para los comunistas. Los perfiles de un discurso nacionalista español socialdemócrata no resultaban compatibles con un concepto del Estado de inspiración soviética. Lo que era singularmente molesto para el PCE fue que Prieto reservara al PSOE un papel como pilar de la recuperación de la democracia frente a los fanatismos de izquierda y derecha. Para finalizar queden unas palabras suyas donde lo perfila simbólicamente:

Soy socialista, pero español. Reconociendo las diversas personalidades regionales que integran nuestra España, otorgo a cada una de ellas el marco que necesiten para su desarrollo y florecimiento; mas dentro de España, con España, perteneciendo a España. (...) que nos guie el recuerdo de Pablo Iglesias, cuya efigie nos preside (...) le veo paseando lentamente, un anciano bajo el acariciador sol invernal de Madrid (...) envuelto en su capa española, porque Pablo Iglesias era símbolo augusto de España ${ }^{64}$.

\section{EL PCE Y MÉXICO}

La acogida en México de los republicanos españoles nació de una sintonía ideológica y personal del general Lázaro Cárdenas con la República. El

\footnotetext{
${ }^{6}$ Emigración política. Caja 133. Socialistas y sindicalistas. Carpeta 1. 1/3 Dirigentes/ Indalecio Prieto Tuero. Artículos de prensa en La Vanguardia de México, 24-6-1940, pág. 12.
} 
atraque del Sinaia en Veracruz en 1939 es el paradigma de la recepción. En palabras de Ávila Camacho había una visión común del 1936 español como "golpe de Estado internacional». Un peligro que no era ajeno a la Revolución mexicana. De ahí las facilidades en otorgar la nacionalidad y permisos de trabajo a los refugiados.

La principal limitación de la actividad de los refugiados en México probablemente fuera su exclusión de la acción política interna. Obviamente su esfuerzo se concentró en la situación de España y en la perspectiva del retorno. Eso no significa que la llegada no tuviera impacto en la esfera pública mexicana. La tendencia a concentrarse en núcleos urbanos era percibida como un riesgo potencial para la estabilidad social. Esta prevención oficial quería evitar las tensiones entre izquierda y derecha. El ascenso de Ávila Camacho a la presidencia satisfacía los deseos de continuidad a cambio de ir concluyendo la tarea programática del cardenismo. Respecto a la emigración, el control económico de la JARE trató de evitar una actividad militante y reconducir la ayuda a lo asistencial sin que los que lleguen puedan «dedicarse a actividades de orden político relacionadas con nuestro país o con el de ellos, sopena de que se les cancele el permiso de residencia ${ }^{65}$.

Estos parámetros limitaron la capacidad de actuación de los comunistas españoles en México. Si los republicanos en su conjunto eran percibidos como amenaza para la estabilidad, los comunistas constituían la quintaesencia de ese prejuicio. Por otro lado allí también se cometía el error de generalizar sobre la emigración española al calificarla de comunista.

La vocación por el interior hace que los esfuerzos del PCE en México se orientaran hacia el mantenimiento de la jerarquía y a las azarosas relaciones con el resto de los republicanos. La atención marginal a los temas mexicanos en la prensa del partido es un ejemplo de este alejamiento del entorno que les acoge ${ }^{66}$. Aunque algunos hechos como el asesinato de Trotsky por Mercader en 1940, vincularan a los comunistas con él, incrementando el recelo oficial hacia el asentamiento republicano en el Distrito Federal, centro neurálgico de la política mexicana.

La relación con el Partido Comunista de México se movió en el ámbito de la solidaridad pero no se constatan injerencias. Ambas organizaciones respetaron su autonomía, estableciéndose contactos personales como con el muralista Diego Rivera. Colaboraron a través de la Escuela de Cuadros del PCM, lo que les proporcionaba un enlace orgánico con la política local del que carecían otras organizaciones. Las gestiones de Dionisio Encina, Secretario General del PCM desde 1940, se encaminaron también a presionar al Gobierno para que mantuviera su política de apertura de fronteras. La respuesta a la propa-

${ }^{65}$ Maldonado, V. A.: «Vías políticas y diplomáticas del exilio», pág 50 y ss. en ABELLÁN, J.L. op. cit. (1982) págs. 25-53.

66 FAGEN W., P.: op. cit., p.131. 
ganda conservadora contraria a los refugiados fue otra tarea en la que encontraron su alianza. EI PCM también sufrió las consecuencias del asesinato de Trotsky y del pacto germano-soviético con procesos de expulsión ${ }^{67}$.

La visión del PCE acerca de México estuvo fijada en buena medida por un concepto de sus relaciones con España, en especial en lo relativo a la creación de la identidad mexicana. Frente a la hispanofobia criolla oponían una versión particular de la historia común donde la conquista y colonización no fueron obra del pueblo español. La explotación a que fue sometido el país era similar a la opresión sufrida en España. Por lo tanto eran dos pueblos hermanos en lucha por la emancipación de las clases dominantes. La raíz liberal de la Guerra de Independencia española no se contrapondría así a la de México, sino que brotarían de un espíritu común ${ }^{68}$. Un porcentaje considerable de los contactos con la sociedad civil y los estamentos mexicanos consistió en realizar llamamientos para la lucha antifranquista. Especialmente, en la protesta internacional como medio para frenar el avance de la represión. La labor de México como intermediario ante las autoridades de Vichy fue puesta como el ejemplo a seguir por los demás países de América.

En plena guerra mundial, la amenaza para México, no provenía sólo de la retórica falangista, sino de un peligroso pulso entre Estados Unidos y la Alemania nazi en torno a Iberoamérica. EI PCE mantuvo una actitud de solidaridad con el presidente Ávila ofreciéndose a colaborar con su trabajo y su experiencia en la lucha contra la barbarie de la agresión nazi-fascista. Para fomentar la colaboración los comunistas apelaron al valor para México de los refugiados:

Corren el peligro de ser devueltos a Franco hombres de ciencia, sabios, catedráticos, militares profesionales, obreros especializados, campesinos, etc.; todo un tesoro que debe ser salvado para la causa de México y de las Democracias y para los que nosotros pedimos, Sr. Presidente, la protección diplomática de Méxi$\mathrm{CO}$, que la noble bandera de nuestra segunda patria cubra y proteja al pueblo español, al verdadero y auténtico pueblo que sufre y lucha abnegadamente en las condiciones del más desenfrenado terror, mientras se realizan todos los esfuerzos posibles para salvarlos del peligro inminente que los acecha ${ }^{69}$.

\footnotetext{
${ }^{\circ}$ Una alusión a estos contactos puede verse en «Un año de solidaridad americana con el pueblo español y a favor de los refugiados" por A. Mije en Nuestra Bandera, Año II, n. 1-2, 1941, págs. 36-37. AHPCE. Publicaciones Periódicas. Las diferencias entre ambos partidos y la ausencia de mezcla se dejan entrever en las palabras de Adolfo Sánchez: «La experiencia personal acumulada en mi práctica polftica junto con la que pude conocer, hacia ya largos años, desde fuera pero cerca, del Partido Comunista Mexicano, me predisponían a una nueva actítud teórica y práctíca" en SÁNCHEZ VÁzOUEZ, A.: op. cit., p. 70. Sobre la expulsión de Hernán Laborde, secretario del PCM y las relaciones con el PCE, Morán, G.: Miseria y grandeza del PCE, 1939-1985, Planeta, Barcelona, 1986.

${ }^{68}$ Una versión bastante completa de esta visión puede hallarse consultando «En el 130 Aniversario de la Independencia de México», Nuestra Bandera, n. 4-5, octubre de 1940, sección Hechos del mes, págs. 93-95. AHPCE. Publicaciones Periódicas.

69 "Carta al SR. Presidente de la República. General de División D. Manuel Ávila Camacho" de Ángel Álvarez, José Marlés, Luis Zapirain, Luis Soto y Federico Melchor. México, mayo de 1942. AHPCE. Documentos del PCE. Carpeta 23. (1942).
} 
México se convirtió así en un escenario de la actividad contra la dictadura de un modo activo y no simplemente como retaguardia para. la clandestinidad. Esta misión quería evitar un giro en la política oficial provocado por la alianza entre las fuerzas conservadoras mexicanas, la antigua colonia residente y la diplomacia española. Nuevamente el caso de Jesús Hernández con su combinación de crítica y defensa pone de manifiesto los límites de la retórica dominante del partido. Según Hernández la terrible merma en la afiliación al partido mexicano se debió a la influencia de Mije como corruptor del secretario general Encinas. Los mexicanos califican a Mije como el "hombre nefasto" para el PCM que no ha hecho sino engrosar las filas del sindicalismo de la CTM con los expulsados de la órbita del PCE ${ }^{70}$.

La delegación basó su sistema de relaciones con el entorno mexicano en función de los criterios del partido. Una tendencia autónoma hubiera sido percibida como movimiento hostil por el anticomunismo local. Tampoco la jerarquía estaba dispuesta a consentir un entendimiento con los demás grupos basado en los intereses y criterios de la emigración de un solo país.

\section{CONCLUSIONES}

Somos espectadores de la Historia. Hemos dejado de ser sus protagonistas ${ }^{71}$.

Parece razonable conceder al exilio político la relevancia que merece dentro de la Historia española del siglo XX. Su aportación no debe ser considerada marginal, ni tampoco como una oportunidad desaprovechada por el sectarismo y el individualismo. Especialmente dada la habilidad del régimen para romper el cerco a un aliado de Hitler y transformarse en pionero anticomunista en el marco de la incipiente Guerra Fría. Una de las más señeras de las aportaciones del exilio al proceso constituyente fue el aprendizaje de las consecuencias negativas de la división. Esta atomización no fue un invento del destierro, sino una prolongación de la España de los años treinta. La formación del consenso que condujo a las elecciones de 1977 no puede comprenderse sin el sacrificio de estos grupos que aprendieron a mantener lo esencial, sacrificando algunos postulados a favor de la reconciliación nacional. La renuncia de Don Juan y la extinción de las instituciones republicanas son ejemplos destacados de este tipo de dolorosas concesiones.

El exilio forma parte de un proceso vigente de recuperación de la memoria histórica en los límites del tiempo presente español. Al silencio impuesto por la dictadura siguió un olvido pactado en la Transición en beneficio de la reconciliación. Ahora se va abriendo un proceso en demanda de rehabilita-

70 «A la delegación del C.C del PC de E. En la Unión Soviética» por Jesús Hernández en México, 2 de abril de 1944. AHPCE. Fondo no catalogado. Divergencias. Correspondencia. Carpeta 1/ 2, págs. 9 y 10.

${ }^{71}$ Luis Araquistain. Cita recogida en ZaPATERO, V. (dir.): Exilio. Catálogo de la Exposición, Fundación Pablo Iglesias, MNCARS, Madrid, 2002, pág.72. 
ción que resulta difícil de consensuar sin despertar controversias políticas ${ }^{72}$. En el fondo late una cierta insatisfacción por no haber sido capaces de provocar la ruptura. La exposición sobre el exilio organizada en 2002 proponía una presentación simbólica de este argumento. La entrada estaba presidida por la bandera y la Constitución de 1931; la salida por sus equivalentes de 1978. Entre estos dos grandes hitos de legitimidad popular el franquismo queda como un larguísimo periodo de usurpación. Entre ambos la dignidad de la soberanía popular fue sostenida por la oposición, especialmente por el exilio. El reconocimiento a esta labor durante la dictadura la caracteriza como un paréntesis y no como fuente de legitimidad ${ }^{73}$.

El estudio del PCE en México puede servir para plantear algunas cuestiones esenciales de la política del exilio. EI PCE ha despertado interés con frecuencia por su papel en el antifranquismo. En este marco cronológico su estudio contribuye al conocimiento de las relaciones entre partidos y plataformas del exilio. Además las características ideológicas confieren a la militancia comunista unas peculiaridades notables para comprender las dificultades de mantener la actividad en el destierro.

La primera cuestión planteada se desarrollaba en torno al aislamiento del PCE en contraste con su voluntad de liderazgo condicionado por singularidades como su vocación por el activismo en España, la dependencia de la URSS y el desarrollo de programas propios como Unión Nacional. Aunque la supeditación del PCE a la dinámica soviética durante el periodo estalinista sea un hecho conocido, no deja de tener relevancia ya que contribuyó a la supeditación de los comunistas españoles en México y al renacimiento de los sentimientos anticomunistas del resto de los grupos. Otro factor que impidió estos contactos fue el vivo recuerdo del proselitismo del PCE en el ejército durante la última fase de la Guerra Civil. Afloraron las diferencias ideológicas con el republicanismo, el liberalismo o las diversas concepciones nacionalistas. Lo que determina que éstas pesasen más que el común repudio a la dictadura fue una voluntad hegemónica que no estaba sustentada en criterios numéricos. Además esta estrategia se desarrolló a través de la captación de militantes en otras organizaciones y del control de asociaciones culturales y sociales, a menudo de forma soterrada.

\footnotetext{
${ }^{72}$ La Comisión Constitucional del Congreso aceptó el 20 de noviembre de 2002 varias proposiciones no de ley modificadas en este sentido. En el difícil debate para la condena del franquismo se liegó a un común denominador: la identificación de España como país defensor de los valores democráticos. De esa identidad surge el reconocimiento moral y cierta reparación material de las víctimas de un régimen contrario a estos principios: A estos ciudadanos y ciudadanas exiliados --así como los llamados niños de la guerra-- supervivientes ya de aquel trágico episodio de nuestra historia, el Congreso de los Diputados considera un deber rendir un tributo de admiración y afecto, por la lealtad a sus convicciones y el sufrimiento que hubieron de padecer por una guerra impropia de una nación cuya razón de ser ha de estar en el respeto a los valores democráticos. Publicado en BOCG. Congreso de los Diputados. 29 de noviembre de 2002. Serie D. N. 448.

${ }^{73}$ Una muestra significativa de recuperación de la memoria es esta exposición impulsada por la Fundación Pablo Iglesias en otoño de 2002, reflejada en ZAPATERO, V. (dir.): Exilio. Catálogo de la Exposición, Fundación Pablo Iglesias, MNCARS, Madrid, 2002.
} 
El segundo planteamiento definía la relación del PCE con la sociedad de acogida, especialmente en lo relativo a su escasa injerencia en la política mexicana. Desde luego el partido volcó su actividad en España, en el mantenimiento de la disciplina interna y en las controvertidas relaciones con los demás exiliados. Como se ha comentado, más allá de la retórica oficial existía una voluntad de las autoridades mexicanas para mantener la actividad política del exilio al margen de las dinámicas de su evolución interna. Hay que considerar que la oposición al cardenismo utilizó como un arma dialéctica cierto rechazo del proceso de acogida. Esta situación dejó a los refugiados en la necesidad de fortalecer su arraigo demostrando sus convicciones democráticas y filomexicanas lejos de radicalismos revolucionarios. Esta dificultad se acrecentaba de modo especial en el caso de los comunistas en un contexto de disciplina prosoviética. La relación con el PC de México se mantuvo en límites de cierta autonomía. Durante el periodo estudiado se comprueba el mantenimiento de dicha separación entre la actividad política orientada a España y el relativo aislamiento de la realidad americana. En parte por la esperanza del retorno y en parte por no despertar la suspicacia del debate público local.

El tercer ámbito planteado examinaba la dificultad en el mantenimiento de una militancia tan exigente en el refugio mexicano. Un país cuya situación social y realidad cotidiana presentaba numerosas diferencias con la España de la época y con el resto de los países del exilio. La dirección en la URSS reprendió frecuentemente a los órganos locales por su sistema de mantenimiento de la jerarquía a través del autoritarismo y de las expulsiones sumarias. Sin embargo, aludía continuamente a la disciplina jerárquica y a la ortodoxia dogmática desde unas condiciones ambientales bien distintas. Esta contradicción no acabó de resolverse satisfactoriamente bajo ninguna estructura directiva ni receta programática. De este hecho se deriva la constante tendencia a emplear un lenguaje y tono muy diferentes en la retórica de la propaganda oficial y en los textos internos de los procesos de depuración. Frente a la pretendida unidad monolítica hay numerosas referencias a labores de división y fraccionamiento. Un gran temor a la contaminación del trotkismo, el titismo, la socialdemocracia o el liberalismo en la línea única de pensamiento y acción defendidas. Resulta llamativo cómo a pesar de presentarse como el partido idóneo para la unidad se produjeron frecuentes quejas del trato dado a intelectuales y antiguos socialistas de militancia reciente. La reconstrucción de la vida familiar o la adquisición de bienes de consumo básicos fue interpretada en ocasiones como un desclasamiento o una traición a los principios marxistas. No cabe señalar un ejemplo más nítido de las dificultades existentes para armonizar la militancia comunista y la adaptación a la vida en México.

Estas premisas acerca del PCE permiten señalar el interés del desarrollo de este estudio con una interpretación más amplia de la relación entre los distintos partidos asentados en México. Por un lado, explorando las dimen- 
siones reales del consenso y de la disputa institucional. Por otro, examinando este proceso a través de la vivencia individual de los militantes. La comparación entre ambas escalas puede ofrecer valiosos matices acerca de las diferencias entre la memoria oficial de los grupos y las perspectivas de sus componentes. Para este objetivo es imprescindible observar las fracturas en la estratigrafía de los recuerdos. Unas historias de vida complejas, cuya evolución normal se vio trastornada profundamente. Su análisis desecha una perspectiva sesgada que contemple las organizaciones políticas como entidades estancas e impersonales ${ }^{74}$.

Obviamente el estudio de la financiación de la ayuda a través de los organismos republicanos permitiría precisar el alcance de dicha fractura política y las condiciones reales del asentamiento e integración de los militantes. En lo que se refiere a México resultaría significativo conocer los límites de la actividad política del exilio como un compartimiento separado de la vida civil mexicana. Por otra parte hay un interesante campo relativo a la actividad de la dictadura en ese país para dificultar las tareas de los refugiados y conseguir el reconocimiento oficial.

La transformación de las relaciones hispano-mexicanas con la llegada de los exiliados no fue sólo política, sino también simbólica. Un episodio que afectó tanto a esta vinculación secular como a las respectivas identidades nacionales. Comprender mejor su impacto sigue siendo un objeto histórico de extraordinario interés.

${ }^{74}$ En este sentido, el proyecto de historia oral elaborado por el Instituto Nacional de Antropología e Historia de México (INAH) en colaboración con el Ministerio de Cultura es un valioso instrumento de indagación. Siguiendo un cuestionario tipo se recopilan datos acerca de los antecedentes personales, su evolución política y el proceso de adaptación al exilio. Como ejemplo de investigación basado en la memoria puede citarse el de una de las autoras de este proyecto: Pla Brugat, D.: Els exiliats catalans a Mèxic. Un estudi de la inmigració republicana, Afers, Catarroja-Barcelona, 2000. 